\title{
Reproductive and Growth Performance in Jin Hua Pigs Cloned from Somatic Cell Nuclei and the Meat Quality of Their Offspring
}

\author{
Masatoshi SHIBATA ${ }^{1}$, Masayoshi OTAKE'), Seiko TSUCHIYA ${ }^{1}$, \\ Mikio CHIKYU ${ }^{1)}$, Atsushi HORIUCHI') and Tatsuo KAWARASAKI') \\ 1)Shizuoka Swine and Poultry Experiment Station, Kikugawa, Shizuoka 439-0037, Japan
}

\begin{abstract}
Somatic cell cloning is expected to be a valuable method for conserving genetic resources in pigs. In this study, we compared the reproductive and growth performance of Jin Hua cloned pigs with that of naturally bred Jin Hua pigs. In addition, we generated offspring from the cloned sows and examined the productivity and quality of meat in the progeny. The birth weights and growth rates of somatic cell-cloned pigs were similar to those of Jin Hua pigs. The cloned pigs reached puberty very early, and this is typical of the Jin Hua breed. Furthermore, reproductive performance, in terms of traits such as gestation period, litter size, and raising rate in the cloned pigs were similar to Jin Hua pigs. Although the offspring of the cloned (OC) pigs had lower birth weights than the Jin Hua breed, the daily weight gain of the OC pigs was significantly higher, especially at the finishing stage. The carcass quality of the OC pigs had similar characteristics to the Jin Hua breed, namely thick back fat and a small loin area. Furthermore, the meat qualities of the OC pigs were similar to those of Jin Hua pigs in terms of intramuscular fat content and tenderness. These results demonstrate that cloned pigs and their offspring were similar to the Jin Hua breed in most of the growth, reproductive, and meat productive performances. This strongly suggests that pigs cloned from somatic cell nuclei have the potential to be a valuable genetic resource for breeding.
\end{abstract}

Key words: Offspring, Pig cloning, Quality of meat, Reproductive performance, Somatic cell

(J. Reprod. Dev. 52: 583-590, 2006)

S uccessful cloning of pigs from somatic cells, using two different methods, was first reported in $2000[1,2]$. Since then, interest in the use of cloned pigs has grown largely because of their potential utility for medical research [3,4]. Somatic cell cloning is also expected to play a part in integrated strategies for conserving pig genetic resources, as cryopreservation of pig embryos is still in development, whereas that for somatic cells is well-established [5]. For the practical application of somatic cell cloning for conservation of genetic

Accepted for publication: May 15, 2006

Published online: June 28, 2006

Correspondence: M. Shibata (e-mail: shibata@sp-exp.pref.shizuoka.jp) resources, it is essential that somatic cell cloned pigs are normal and that they share the characteristic traits of the progenitor. It has been reported that cloned pigs are healthy for 3 to 8 months after birth $[2,6,7]$. Furthermore, Archer et al. [8] compared clinical parameters of cloned, experimental pigs up to 27 weeks of age with ageand breed-matched controls. They found that the phenotypic variability of the cloned pigs fell within the normal range. To date, however, there has been no report on whether both somatic cell-cloned pigs and their offspring have the characteristics of the nucleus donor breed.

In this study, we examined the growth and reproductive performance of Jin Hua pigs cloned 
Table 1. Summary of the somatic cell-cloned Jin Hua pigs

\begin{tabular}{|c|c|c|c|c|c|c|c|}
\hline \multirow[b]{2}{*}{ Clone } & \multirow[b]{2}{*}{ Date of birth } & \multirow[b]{2}{*}{$\begin{array}{l}\text { Weight at } \\
\text { birth }(\mathrm{kg})\end{array}$} & \multicolumn{3}{|c|}{ Nucleus donor pigs } & \multicolumn{2}{|c|}{$\begin{array}{c}\text { Age and weight of cloned } \\
\text { pigs at puberty }\end{array}$} \\
\hline & & & $\begin{array}{l}\text { Age at sampling } \\
\text { of somatic cells }\end{array}$ & Sex & $\begin{array}{c}\text { Source of } \\
\text { somatic cells }\end{array}$ & $\begin{array}{l}\text { Age } \\
\text { (days) }\end{array}$ & $\begin{array}{l}\text { Weight } \\
(\mathrm{kg})\end{array}$ \\
\hline S-1 & '02.6.21 & 0.95 & 118 days & Female & Ear & 125 & 57.5 \\
\hline S-2 & '02.6.21 & 1.00 & & & skin & 175 & 51.7 \\
\hline S-3 & '02.7.26 & 0.90 & & & & 97 & 42 \\
\hline O-1 & '02.10.9 & 0.50 & 1 day & Female & Oviduct & 114 & 28 \\
\hline $\mathrm{O}-2$ & '02.11.8 & 0.90 & & & & 113 & 42.5 \\
\hline $\mathrm{O}-3$ & '02.11.8 & 1.05 & & & & 106 & 37.5 \\
\hline $\mathrm{O}-4$ & '03.3.7 & 1.10 & & & & 102 & 36 \\
\hline \multirow[t]{2}{*}{$\mathrm{E}-1$} & '03.6.27 & 0.95 & 1 day & Female & $\begin{array}{l}\text { Ear } \\
\text { skin }\end{array}$ & 89 & 36.5 \\
\hline & & & & \multicolumn{2}{|c|}{ Average } & 115.1 & 41.5 \\
\hline
\end{tabular}

from somatic cell nuclei and the productivity and quality of meat in their offspring (OC). We compared these characteristics to those of naturally bred Jin Hua and Duroc pigs. This data enabled us to examine whether cloned pigs will be a useful genetic resource in livestock agriculture.

\section{Materials and Methods}

\section{Animals}

Jin Hua pigs cloned from somatic cell nuclei: Somatic cells from the skin or oviduct were cryopreserved and used as nucleus donors after thawing (Table 1). Recipient oocytes were collected from Large White Duroc and Duroc $\times$ Landrace cross sows. Donor nuclei were introduced into enucleated oocytes using piezo-actuated microinjection [1]. The reconstructed embryos were activated by a single direct current pulse of $150 \mathrm{kV} / \mathrm{cm}$ for $99 \mu \mathrm{sec}$. After 20 to $68 \mathrm{hr}$ of culture, the embryos were transferred to the oviducts of surrogate sows. Four to 5 in vivo-fertilized embryos (Duroc, Large White, Landrace, or crossbreeds of them) were cotransferred as an aid to maintain pregnancy. Eight cloned sows were produced from 6 litters; four of the cloned pigs were derived from ear skin cells and 4 were derived from oviduct cells. Microsatellite DNA analysis was used to confirm that the presumptive clones were genetically identical (data not shown).

Offspring of the cloned (OC) pigs: Six of the cloned sows were artificially inseminated with semen from naturally bred Jin Hua boars. Forty- four OC pigs ( 23 male and 21 female) were obtained from 6 litters for use in this study (Table 2).

Control pigs used for each experiment: We used naturally bred pigs as controls. To compare growth from birth to 8 weeks with cloned pigs, 50 control females from 16 litters delivered between September 2000 and January 2003 were used. Eight first-farrowing sows were used as controls for the comparison of reproductive characteristics. The pigs chosen as controls underwent parturition between 333 and 398 days of age. They were selected to match the mean age at parturition of the cloned pigs. To compare productivity and quality of meat with the OC pigs, 21 Jin Hua animals (12 males and 9 females) from 3 litters delivered between April 2000 and October 2003 and 27 Duroc (18 males and 9 females) from 12 litters delivered between June 2000 and April 2001 were used as controls.

Animal management: All experimental pigs were bred under an SPF environment and had ad libitum access to food and water in accordance with the standard practice at our experiment station. As is usual for pigs grown for meat, males were castrated at 1 to 10 weeks to maintain the quality of meat and to prevent uncontrolled breeding.

\section{Measurements and analysis}

Growth and reproductive performance: The pigs were weighed weekly. Assessment of reproductive performance was carried out using the following range of characteristics: the time of puberty (defined as receptivity to the boar); the length of the gestation period (from the first day of mating to 
Table 2. Time of parturition and litter productivity performance of cloned pigs and summary of offspring

\begin{tabular}{|c|c|c|c|c|c|c|c|c|c|c|c|}
\hline \multirow{3}{*}{ Clone } & \multicolumn{7}{|c|}{ Time of parturition and litter productivity performance } & \multicolumn{4}{|c|}{ Summary of offspring } \\
\hline & \multirow{2}{*}{$\begin{array}{l}\text { Gestation } \\
\text { period } \\
\text { (days) }\end{array}$} & \multicolumn{3}{|c|}{ Number of piglets } & \multirow[b]{2}{*}{$\begin{array}{l}\text { Rising } \\
\text { rate }\end{array}$} & \multicolumn{2}{|c|}{ Mean weight $(\mathrm{kg})$ at } & \multirow[b]{2}{*}{ Boar** } & \multirow{2}{*}{$\begin{array}{c}\text { Date of } \\
\text { litter }\end{array}$} & \multirow{2}{*}{\multicolumn{2}{|c|}{$\begin{array}{c}\begin{array}{c}\text { Number of } \\
\text { offspring examined } \\
\text { Male }^{* * *} \text { Female }\end{array} \\
\end{array}$}} \\
\hline & & Total & $\begin{array}{l}\text { Born } \\
\text { alive }\end{array}$ & Weaned & & Birth & 3 weeks & & & & \\
\hline$S-1^{a}$ & 112 & 13 & 11 & $(10)^{\mathrm{b}}$ & $(90.9)^{\mathrm{b}}$ & 0.60 & $(2.53)^{\mathrm{b}}$ & $01-0421$ & '03. 6.15 & 3 & 2 \\
\hline S-2 & 113 & 9 & 9 & 8 & 88.9 & 0.76 & 3.64 & $00-0776$ & '03. 6.22 & 5 & 3 \\
\hline S-3 & 114 & 13 & 11 & 10 & 90.9 & 0.69 & 2.93 & 00-0776 & '03. 7.4 & 5 & 4 \\
\hline O-1 & 112 & 9 & 9 & 8 & 88.9 & 0.79 & 2.38 & 00-0776 & '03.10.9 & 2 & 3 \\
\hline $\mathrm{O}-2$ & 112 & 9 & 9 & 9 & 100 & 0.73 & 2.90 & 00-0776 & '03.10.25 & 4 & 4 \\
\hline $\mathrm{O}-3$ & 112 & 12 & 12 & 7 & 58.3 & 0.71 & 2.86 & 00-0776 & '03.11.18 & 4 & 5 \\
\hline \multirow[t]{2}{*}{ Average } & 112.5 & 10.8 & 10.2 & 8.4 & 85.4 & $0.74^{*}$ & 2.94 & & & & \\
\hline & \pm 0.34 & \pm 0.8 & \pm 0.5 & \pm 0.5 & \pm 7.1 & \pm 0.02 & \pm 0.20 & & Total & 23 & 21 \\
\hline \multirow[t]{2}{*}{ Jin $\mathrm{Hua}^{\mathrm{c}}$} & 113.4 & 11.0 & 10.0 & 9.1 & 90.6 & 0.89 & 3.94 & & & & \\
\hline & \pm 0.4 & \pm 0.7 & \pm 0.8 & \pm 1.0 & \pm 6.0 & \pm 0.05 & \pm 0.42 & & & & \\
\hline
\end{tabular}

${ }^{a}$ Hypogalactia. ${ }^{b}$ Figures in parentheses are not included in the average for each category. ${ }^{c}$ Average of 9 sows of similar ages. *Values are significantly different $(\mathrm{P}<0.05)$. ${ }^{* *}$ Boars used as semen donors for artificial insemination. ${ }^{* * *}$ Male pigs were castrated at 1 to 10 weeks. Jin Hua: naturally bred Jin Hua pigs.

parturition); the litter size (including fetal deaths); the number of live piglets born; survival to weaning (living piglets at 3 weeks of age); the rising rate (number of piglets at weaning/number born alive); and the mean weights of living piglets at birth and after 3 weeks.

Meat productivity and carcass traits of the offspring of the cloned pigs: We estimated the daily weight gain of the OC pigs using the length of time they took to reach 30 and $70 \mathrm{~kg}$ body weight. All experimental pigs were slaughtered at $70 \mathrm{~kg}$ body weight. The carcasses were chilled overnight and then the back and loin length (from the front edge of the first thoracic vertebra to the back edge of the final lumbar vertebra) and back fat thickness (shoulder, rib, lumbar) were measured. The number of lumbar and thoracic vertebrae was counted. Subsequently, each carcass was cut between the 4 th and 5 th thoracic vertebrae and the last lumbar vertebra. The weight ratio of the three blocks (shoulder, loin bacon, and ham) was measured. The loin eye between the 4 th and 5 th thoracic vertebrae was traced and the area measured using a polar planimeter.

Examination of meat quality: The longissimus dorsi from the last thoracic vertebra to the 4 th lumbar vertebra was removed from the carcass and used to examine the quality of the meat. Each sample was minced and dried inside an aluminum can for $2 \mathrm{~h}$ at $135 \mathrm{C}$. The amount of intramuscular water was estimated by weighing samples before and after drying. Subsequently, lipids were extracted from the dried samples with ether. Measurement of $\mathrm{pH}$ was carried out using a portable $\mathrm{pH}$ meter (Horiba, Ltd., Kyoto, Japan).

To determine the water holding capacity of the meat, we measured weep loss and cooking loss. For the measurement of weep loss, each sample was cut into blocks $3 \mathrm{~cm}$ long $\times 3 \mathrm{~cm}$ wide $\times 1 \mathrm{~cm}$ thick and was then wrapped and suspended for 5 days at $4 \mathrm{C}$. The blocks were weighed before and after this procedure. For measurement of cooking loss, we cut the meat into blocks $3 \mathrm{~cm}$ long $\times 2 \mathrm{~cm}$ wide $\times 2 \mathrm{~cm}$ deep and cooked the blocks for $1 \mathrm{~h}$ at $70 \mathrm{C}$ in a vacuum vinyl bag. The blocks were then cooled for $30 \mathrm{~min}$ in the draining water. Cooking loss was measured by weighing the blocks before and after cooking. The cooked blocks were then cut into $1 \mathrm{~cm} \times 1 \mathrm{~cm}$ segments to determine the shear value using a Warner-Bratzler shear measurement device (Model 235, G-R Manufacturing Co., Manhattan, NY, USA).

Statistical analysis: T-test were performed during statistical analysis using the StatView software (SAS Institute, Cary, NC, USA).

\section{Results}

\section{Growth and reproductive performance of the cloned} pigs

The body weights over the first 8 weeks after 


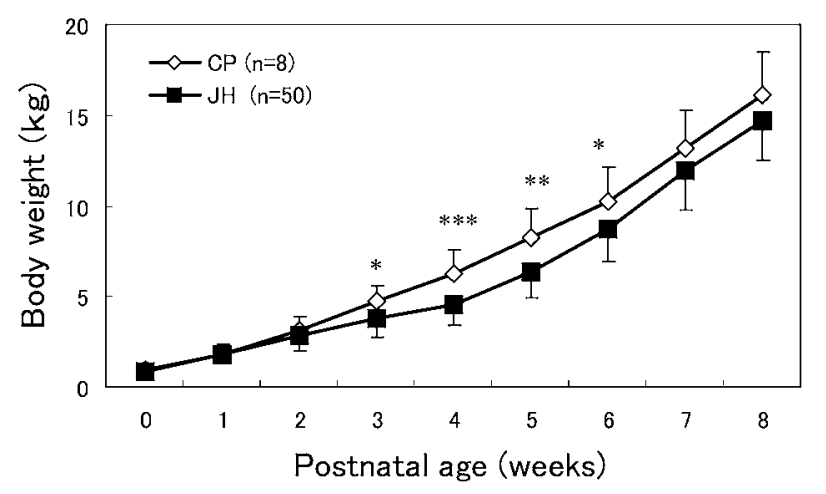

Fig. 1. Comparison of body weights of somatic cell-cloned and naturally bred Jin Hua pigs for the first 8 weeks after birth.

$*: \mathrm{P}<0.05 .{ }^{* *}: \mathrm{P}<0.01$. $^{* *}: \mathrm{P}<0.001$.

$\mathrm{CP}$ : cloned Jin Hua pigs. Jin Hua $(\mathrm{JH})$ : naturally bred Jin Hua pigs.

birth of the cloned and Jin Hua pigs are presented in Fig. 1. The cloned pigs were born either in a litter of one or in a mixed litter with piglets derived from cotransferred normal embryos as an aid to maintain pregnancy. The litter size was 1 to 6 . The mean birth weight of the cloned pigs, excluding fetal deaths and piglets crushed within a few days of birth, was $0.91 \mathrm{~kg}$. This mean weight was similar to that of the Jin Hua piglets $(0.87 \mathrm{~kg})$. No large offspring, i.e. 1.5 times heavier than the mean weight, were observed. Between 3 and 6 weeks of age, the cloned piglets were significantly heavier than the Jin Hua animals $(\mathrm{P}<0.05)$. However, there was no significant difference between them after the seventh week. Subsequently, the cloned pigs grew at the same rate as the Jin Hua animals. The cloned pigs also displayed the usual body characteristics of the Jin Hua breed, such as coat color, a hollowed back, and pendulous abdomen.

The age at puberty for the cloned pigs is presented in Table 1. The cloned gilts showed clear receptivity behavior to boars at between 89 to 125 days of age, except for one gilt at 175 days. Subsequently, seven of the cloned gilts, including S-2, were artificially inseminated with semen from a naturally bred Jin Hua boar. The first artificial insemination was conducted when the gilts were between 217 to 270 days of age in accordance with the standard practice at our experiment station, except in the case of one gilt (E-1, conducted at 427 days). After 2 to 4 cycles of artificial insemination, all seven cloned gilts conceived during the first estrus cycle and farrowed spontaneously.

The lengths of pregnancies, litter sizes, and growth of the piglets before weaning are presented in Table 2. One sow (S-1) showed hypogalactia, so her offspring were fed artificially. Therefore, the data from this litter was not included in the comparison between cloned and naturally bred Jin Hua pigs. There were no differences between the cloned and Jin Hua pigs with regard to mean litter size (10.8 vs 11.0), the number of piglets born alive (10.2 vs 10.0), and the number of piglets at weaning (8.4 vs 9.1). The mean birth weight of the cloned pigs $(0.71 \mathrm{~kg})$, however, was significantly lower than that of the Jin Hua pigs $(0.87 \mathrm{~kg} ; \mathrm{P}<0.05)$.

Productivity and quality of the meat of the offspring of the cloned pigs

The growth rates of the offspring of the cloned (OC) pigs and naturally bred Jin Hua and Duroc pigs are presented in Table 3 . The daily weight gain was not significantly different between the OC and Jin Hua pigs from birth to $30 \mathrm{~kg}$ of weight. However, from $30 \mathrm{~kg}$ to $70 \mathrm{~kg}$ of weight, the daily gain was significantly higher in the $\mathrm{OC}$ than Jin Hua pigs (549.0 g vs 444 g; $\mathrm{P}<0.001$ ). The birth weights and daily weight gains were significantly higher in the Duroc pigs than the OC and Jin Hua pigs (1.60 vs 0.72 and $0.91 ; 867.7$ vs 549.0 and 444.0, respectively; $\mathrm{P}<0.001)$. Although a significant difference was observed in birth weights between the $O C$ and Jin Hua pigs, the Duroc pig were obviously larger than them at birth.

The carcass trait data for the OC, Jin Hua and Duroc pigs are presented in Table 4 . The back fat thickness of the OC pigs was similar to that of the Jin Hua pigs and was thicker than that of the Duroc pigs $(\mathrm{P}<0.01)$. The loin eye areas of the $\mathrm{OC}$ and Jin Hua pigs were similar and were significantly smaller than that of the Duroc pigs $(\mathrm{P}<0.01)$. There was a difference in the weight ratios of the loin bacon and ham carcass blocks. The ratios of the loin bacon of the $\mathrm{OC}$ and Jin Hua pigs were significantly higher than that of the Duroc pigs $(P<0.01)$. In contrast, the ratios of the ham of the $\mathrm{OC}$ and Jin Hua pigs were significantly lower than that of the Duroc pigs $(\mathrm{P}<0.01)$.

With regard to meat quality, the $\mathrm{OC}$ and Jin Hua pigs had significantly lower water content and higher fat content than the Duroc $(\mathrm{P}<0.01$; Table 5). Moreover, the shear value of the meat from the OC and Jin Hua pigs was significantly lower than that 
Table 3. Comparison of birth weight and daily gain in offspring of somatic cell-cloned, naturally bred Jin Hua and Duroc breed pigs

\begin{tabular}{lcccc}
\hline Source of & $\begin{array}{c}\text { No. of pigs } \\
\text { pigs }\end{array}$ & $\begin{array}{c}\text { Weight at birth } \\
(\mathrm{kg})\end{array}$ & \multicolumn{2}{c}{ Daily gain $(\mathrm{g})$ during } \\
\cline { 4 - 5 } OC & 44 & $0.72 \pm 0.02^{\mathrm{A}}$ & $308.6 \pm 4.5^{\mathrm{A}}$ & 30 to $70 \mathrm{~kg}$ of weight \\
\hline Jin Hua & 21 & $0.91 \pm 0.05^{\mathrm{B}}$ & $314.6 \pm 4.0^{\mathrm{A}}$ & $449.0 \pm 9.3^{\mathrm{A}}$ \\
\hline $\mathrm{D}$ & 27 & $1.60 \pm 0.05^{\mathrm{C}}$ & $403.8 \pm 48.2^{\mathrm{B}}$ & $867.7 \pm 29.0^{\mathrm{C}}$ \\
\hline
\end{tabular}

Mean \pm SE.

$A, B, C$ Values with different superscripts differ within each columns $(\mathrm{P}<0.001)$.

OC: offspring of cloned Jin Hua pigs. Jin Hua: naturally bred Jin Hua pigs. D: Duroc breed.

Table 4. Comparison of carcass traits of somatic cell-cloned, naturally bred Jin Hua, and Duroc breed pigs

\begin{tabular}{lccc}
\hline & OC & Jin Hua & n=30 \\
& $54.1 \pm 0.31^{\mathrm{A}}$ & $56.0 \pm 0.32^{\mathrm{B}}$ & $\begin{array}{c}\mathrm{D} \\
\mathrm{n}=27\end{array}$ \\
\hline Back and loin length $(\mathrm{cm})$ & $19.4 \pm 0.9^{\mathrm{Ax}}$ & $19.7 \pm 0.8^{\mathrm{Ay}}$ & $57.6 \pm 0.25^{\mathrm{C}}$ \\
Number of vertebrae & & & $21.1 \pm 0.8^{\mathrm{B}}$ \\
Back fat thickness (cm) & $5.3 \pm 0.1^{\mathrm{A}}$ & $5.2 \pm 0.1^{\mathrm{A}}$ & $3.2 \pm 0.1^{\mathrm{B}}$ \\
$\quad$ Shoulder & $2.9 \pm 0.7^{\mathrm{A}}$ & $2.8 \pm 0.9^{\mathrm{A}}$ & $1.8 \pm 0.7^{\mathrm{B}}$ \\
$\quad$ Rib & $3.6 \pm 0.1^{\mathrm{A}}$ & $3.3 \pm 0.1^{\mathrm{A}}$ & $2.7 \pm 0.1^{\mathrm{B}}$ \\
$\quad$ & & \\
Lumbar & $31.4 \pm 0.2^{\mathrm{B}}$ & $31.6 \pm 0.3$ & $31.2 \pm 0.2$ \\
$\quad$ Shoulder & $40.6 \pm 0.2^{\mathrm{A}}$ & $41.9 \pm 0.4^{\mathrm{B}}$ & $36.3 \pm 0.4^{\mathrm{C}}$ \\
$\quad$ Loin bacon & $27.9 \pm 0.3^{\mathrm{A}}$ & $26.5 \pm 0.2^{\mathrm{B}}$ & $32.5 \pm 0.3^{\mathrm{C}}$ \\
$\quad$ Ham & $9.8 \pm 0.3^{\mathrm{A}}$ & $9.7 \pm 0.2^{\mathrm{A}}$ & $14.8 \pm 0.3^{\mathrm{B}}$ \\
Loin eye area $\left(\mathrm{cm}^{2}\right)$ &
\end{tabular}

Mean \pm SE.

Values with different capital and small letter superscripts differ within rows $(\mathrm{P}<0.01$ and 0.05 , respectively).

OC: offspring of cloned Jin Hua pigs. Jin Hua: naturally bred Jin Hua pigs. D: Duroc breed.

Table 5. Comparison of meat quality of somatic cell-cloned, naturally bred Jin Hua, and Duroc breed pigs

\begin{tabular}{lccc}
\hline & OC & Jin Hua & n $=19$ \\
& $\mathrm{n}=27$ & $70.6 \pm 0.4^{\mathrm{A}}$ & $\mathrm{D}=27$ \\
\hline Water content $(\%)$ & $70.2 \pm 0.2^{\mathrm{A}}$ & $4.2 \pm 0.3^{\mathrm{A}}$ & $73.3 \pm 0.1^{\mathrm{B}}$ \\
Fat content $(\%)$ & $4.2 \pm 0.3^{\mathrm{A}}$ & $5.67 \pm 0.03^{\mathrm{Bx}}$ & $3.1 \pm 0.1^{\mathrm{B}}$ \\
$\mathrm{pH}$ & $5.47 \pm 0.01^{\mathrm{A}}$ & $7.56 \pm 0.43$ & $5.56 \pm 0.03^{\mathrm{By}}$ \\
Weep loss $(\%)$ & $6.69 \pm 0.24$ & $24.89 \pm 0.35^{\mathrm{B}}$ & $7.37 \pm 0.41$ \\
Cooking loss $(\%)$ & $26.80 \pm 0.26^{\mathrm{A}}$ & $5.44 \pm 0.23^{\mathrm{a}}$ & $28.99 \pm 0.57^{\mathrm{C}}$ \\
Shear value $\left(\mathrm{lb} / \mathrm{cm}^{2}\right)$ & $5.65 \pm 0.25^{\mathrm{a}}$ & $7.38 \pm 0.68^{\mathrm{b}}$ \\
\hline
\end{tabular}

Mean \pm SE.

Values with different capital and small letter superscripts differ within rows ( $\mathrm{P}<0.01$ and 0.05 , respectively).

OC: offspring of clone Jin Hua pigs. Jin Hua: naturally bred Jin Hua pigs. D: Duroc breed.

of the Duroc pigs $(\mathrm{P}<0.05$; Table 5). However, there were no significant differences in the rates of weep loss between them (Table 5). Cooking loss and $\mathrm{pH}$ differed in the 3 groups of pigs $(\mathrm{P}<0.01$ and 0.01 or 0.05 , respectively; Table 5).

\section{Discussion}

In this study, we examined the growth and reproductive performances of Jin Hua pigs cloned from somatic cell nuclei and the productivity and quality of meat in their offspring. Comparison with naturally bred Jin Hua and Duroc pigs 
demonstrated that the cloned pigs retained the characteristics of the progenitor Jin Hua breed. This is the first study to show that pigs cloned from somatic cells have the characteristics of the nucleus donor breed.

With respect to the use of somatic cell cloning for producing livestock, the largest number of studies has been carried out in cattle. Somatic cell-cloned cattle show a range of abnormalities, the so-called "cloning syndrome". These include higher rates of pregnancy loss, higher birth weights, and higher rates of post-natal mortality [9]. However, clones that survive beyond the perinatal period have similar clinical and reproductive characteristics to cattle obtained by artificial insemination [10-14]. Moreover, the food safety of products from cloned cattle has also been examined $[15,16]$. The compositions of milk [14, 17] and of beef [16] derived from cloned cattle do not differ from those of non-cloned cattle.

In contrast to the experience with cattle, no postnatal abnormalities have been observed in somatic cell cloned pigs [6-8,18]. Likewise, on our experimental station, we have seen no typical "cloning syndrome" abnormalities as reported in cattle. The only possible exception is crushed piglets, but these can also occur in litters of conventionally bred pigs (data not shown). It is not clear why such cloning syndrome traits have not been identified in cloned pigs so far. One possible explanation is that abnormal fetuses do not reach birth, but instead perish at an early period of gestation because the rate of success is low in relation to the number of transferred cloned embryos.

The Jin Hua breed originated in the Zhejiang Province of China. These pigs have a typical adult weight of around $150 \mathrm{~kg}$ and a reputation for producing high quality ham [19]. When the growth rates of the cloned and naturally bred Jin Hua pigs were compared, the former showed significantly heavier rates at 3 to 6 weeks than those of the latter. It is not clear whether this was caused by the cloning techniques. However, the difference in weight between the cloned and naturally bred Jin Hua pigs disappeared after 7 weeks. Furthermore, the degree of leaning of the graph was similar except for around weaning. Overall, therefore, we conclude that the growth of the cloned pigs was essentially identical to that of the naturally bred Jin Hua pigs.
Jin Hua pigs reach puberty very early, at around $109 \pm 15$ days [20]. Swelling of the vulva is one of the signs of heat that is not clear in Jin Hua pigs. So, in this study, the onset of puberty of the cloned pigs was determined by their receptivity to a boar. We found that the age of puberty was within the published range, except for one gilt (S-2). Thus, the characteristic precocity of the Jin Hua breed seemed to be shown by the cloned pigs. In addition, S-2 showed some periodic appetite declines, which might suggest estrus, before evident receptivity. They showed estrus regularly afterwards; the length of the estrous cycle was 18-22 days, and the duration of estrus was 2-3 days.

Seven of the cloned sows were artificially inseminated with semen from a naturally bred Jin Hua boar. All of them conceived during the first estrus cycle, and all subsequently farrowed spontaneously. Parturition parameters, such as mean litter size, the number of piglets born alive, and the number of piglets alive at weaning, are influenced by the age at parturition in the Jin Hua breed [19]. Thus, dams at 360 days old, when parturition should occur, were used to compare parturition parameters in the cloned and Jin Hua pigs. It was found that mean litter size, the number of piglets born alive, and the number of piglets surviving to weaning in the cloned pigs were similar to those of the Jin Hua pigs. Although there was a significant difference in the birth weights of the piglets between the cloned and naturally bred pigs, the difference disappeared at weaning. From these results, we conclude that cloned Jin Hua pigs have similar characteristics to conventionally bred Jin Hua pigs.

Currently, the efficiency of producing somatic cell cloned pigs is extremely low, and so improvement in the technology is necessary before it will be practicable for livestock agriculture. It has been reported that the higher birth weights and placental abnormalities frequently observed in cloned mice, sheep, and cattle are not present in their offspring $[9,21-23]$. Confirmation of the normality of the progeny of cloned pigs is urgently required for the use of clones as breeding stock.

We produced offspring from the cloned sows by artificial insemination with semen from a naturally bred Jin Hua boar. We examined the growth, productivity, and quality of meat in the progeny of the cloned pigs to ascertain whether their traits were inherited from the Jin Hua breed. When daily 
gain was compared, the offspring of the cloned pigs showed a significantly higher gain, especially at the finishing stage, than the Jin Hua pigs, but this was significantly lower than that seen in the Duroc breed. Thus, we concluded that the offspring of the cloned pigs had the characteristics of small breeds in growth performance.

The carcasses of Jin Hua pigs are characteristically different from the Duroc breed in terms of back fat thickness, weight ratio of the three carcass blocks (except for the shoulder), and the loin eye area. The back fat thickness and loin eye area of the OC pigs were similar to those of the Jin Hua pigs but they were clearly different from those of the Duroc breed. Although the weight ratios of the loin bacon and ham were different between the OC and Jin Hua pigs, both had characteristically smaller ham and larger loin bacon than the Duroc breed. The Duroc breed had the longest back and loin lengths, while the OC pigs had the shortest. Generally, as back and loin lengths increase, the numbers of vertebrae also increase and this slows the growth of the animal $[24,25]$. Thus, although these factors may influence the difference in daily gain in the OC and Jin Hua pigs, they do not alter the general carcass traits of the breed.

When the quality of meat was compared between the OC, Jin Hua, and Duroc breed pigs, $\mathrm{pH}$ and cooking loss, which is influenced by $\mathrm{pH}$, were different between the $\mathrm{OC}$ and Jin Hua pigs. However, the OC pigs had the same intramuscular fat and shear value characteristics, an index of the tenderness of the meat, as the Jin Hua pigs. Both the OC and Jin Hua pigs differed from the Duroc breed. Intramuscular fat is reportedly related to the taste characteristics of pork [26]; both tenderness and intramuscular fat are particularly favored in Japan [27]. These traits, present in both the Jin Hua and OC pigs, are therefore very important to Japanese consumers.

From these results, we conclude that the offspring of somatic cell-cloned Jin Hua pigs retain most of the growth and meat quality characteristics of naturally bred Jin Hua pigs. On the basis of this conclusion, we suggest that it will not only be feasible to use somatic cell-cloned pigs and their offspring in livestock production, but that this technique will also be valuable for preserving and increasing the genetic resources of swine.

However, it should be noted that studies on the safety to humans of food products from the progeny of cloned animals are essential before somatic cell-cloned animals can be used for conserving genetic resources.

\section{Acknowledgements}

The authors wish to thank Dr. Takashi Nagai and Dr. Akira Onishi for critical reading of this manuscript. This research was supported in part by grants for a research project for utilizing advanced technologies in agriculture, forestry and fisheries. Part of this study was supported by Grant-in-Aid (\#1672) for a research project for utilizing advanced technologies in agriculture, forestry and fisheries from the Ministry of Agriculture, Forestry and Fisheries of Japan.

\section{References}

1. Onishi A, Iwamoto M, Akita T, Mikawa S, Takeda K, Awata T, Hanada H, Perry AC. Pig cloning by microinjection of fetal fibroblast nuclei. Science 2000; 289: 1188-1190.

2. Polejaeva IA, Chen SH, Vaught TD, Page PL, Mullins J, Ball S, Dai Y, Boone J, Walker S, Ayares DL, Colman A, Campbell KH. Cloned pigs produced by nuclear transfer from adult somatic cells. Nature 2000; 407: 86-90.

3. Park KW, Lai L, Cheong HT, Cabot R, Sun QY, Wu G, Rucker EB, Durtschi D, Bonk A, Samuel M, Rieke A, Day BN, Murphy CN, Carter DB, Prather RS. Mosaic gene expression in nuclear transferderived embryos and the production of cloned transgenic pig from ear-derived fibroblasts. Biol Reprod 2002; 66: 1001-1005.

4. Phelps CJ, Koike C, Vaught TD, Boone J, Wells KD, Chen SH, Ball S, Specht SM, Polejaeva IA, Monahan JA, Jobst PM, Sharman SB, Lamborn AE, Garst AS, Moore M, Demetris AJ, Rudert WA, Bottino R, Bertera S, Trucco M, Starzl TE, Dai Y, Ayares DL. Production of alpha 1,3-galactosyltrasferase deficient pig. Science 2003; 299: 411-414.

5. Onishi A. Cloning of pigs from somatic cells and its prospects. Cloning Stem Cells 2002; 4: 253-259.

6. Yin XJ, Tani T, Yonemura I, Kawakami M, Miyamoto K, Hasegawa R, Kato Y, Tsunoda Y. Production of cloned pig from adult somatic cells by 
chemically assisted removal of maternal chromosomes. Biol Reprod 2002; 67: 442-446.

7. Boquest AC, Grupen CG, Harrison SJ, Mcllfatrick SM, Ashman RJ, d'Apice AJF, Nottle MB. Production of cloned pigs from cultured fetal fibroblast cells. Biol Reprod 2002; 66: 1283-1287.

8. Archer GS, Dindot S, Friend TH, Walker S, Zaunbrecher G, Lawhorn B, Piedrahite JA. Hierarchical phenotypic and epigenetic variation in cloned swine. Biol Reprod 2003; 69: 430-436.

9. Wells DN, Forsyth JT, McMillan V, Oback B. The health of somatic cell cloned cattle and their offspring. Cloning Stem Cells 2004; 6: 101-110.

10. Lanza RP, Cibelli JB, Faber D, Sweeney RW, Henderson B, Nevala W, West MD, Wettstein PJ. Cloned cattle can be healthy and normal. Science 2001; 294: 1893-1894.

11. Chavatte-Palmer P, Heyman $Y$, Richard C, Monget P, LeBourhis D, Kann G, Chiliard Y, Vignon X, Renard JP. Clinical, hormonal, and hematologic characteristics of bovine calves derived from nuclei from somatic cells. Biol Reprod 2002; 66: 1596-1603.

12. Enright BP, Taneja M, Schreiber D, Riesen J, Tian $X C$, Fortune JE, Yang $X$. Reproductive characteristics of cloned heifers derived from adult somatic cells. Biol Reprod 2002; 66: 291-296.

13. Pace MM, Augenstein ML, Betthauser JM, Childs LA, Eilertsen KJ, Enos JM, Forsberg EJ, Golueke PJ, Graber DF, Kemper JC, Koopang RW, Lange G, Lesmeister TL, Mallon KS, Mell GD, Misica PM, Pfister-Genskow M, Strelchenko NS, Voelker GR, Watt SR, Bishop MD. Ontogeny of cloned cattle to lactation. Biol Reprod 2002; 67: 334-339.

14. Yonai M, Kaneyama N, Miyashita N, Kobayashi S, Goto Y, Bettpu T, Nagai T. Growth and fertility of bulls cloned from the somatic cells of an aged and infertile bull. J Dairy Sci 2005; 88: 4097-4110.

15. Rudenko L, Matheson JC, Adams AL, Dubbin ES, Greenlees KJ. Food consumption risk associated with animal clones: what should be investigated? Cloning Stem Cells 2004; 6: 79-93.

16. Takahashi S, Ito Y. Evalution of meat products from cloned cattle: biological and biochemical properties. Cloning Stem Cells 2004; 6: 165-171.

17. Walsh MK, Lucey JA, Govindasamy-Lucey S, Pace
MM, Bishop MD. Comparison of milk produced by cow cloned by nuclear transfer with milk from noncloned cows. Cloning Stem Cells 2003; 5: 213-219.

18. Lee JW, Wu SC, Tian XC, Barber M, Hoagland T, Riesen J, Lee KH, Tu CF, Cheng WTK, Yang X. Production of cloned pigs by whole-cell intracytoplasmic microinjection. Biol Reprod 2003; 69: 995-1001.

19. Bidanel JP, Caritez JC, Legault C. Ten years of experiments with Chinese pigs in France. 1. Breed evaluation. Pig news and information 1990; 11: 345348.

20. Legault C, Caritez JC. Experiments with Chinese pig in France. I. Reproductive performance in purebreds and crossbreeding with European breeds. Genet Sel Evol 1983; 15: 225-240.

21. Tamashiro KL, Wakayama T, Akutsu H, Yamazaki Y, Lachey JL, Wortman MD, Seeley RJ, D'Alessio DA, Woods SC, Yanagimachi R, Sakai RR. Cloned mice have an obese phenotype not transmitted to their offspring. Nat Med 2002; 8: 215-216.

22. Wells DN. Cloning in livestock agriculture. Reprod Suppl 2003; 61: 131-150.

23. Shiga K, Umeki H, Shimura H, Fujita T, Watanabe S, Nagai T. Growth and fertility of bulls cloned from the somatic cells of an aged and infertile bull. Theriogenology 2005; 64: 334-343.

24. King JWB, Roberts RC. Carcass length in the bacon pig: its association with vertebrae numbers and prediction from radiographs of the young pig. Anim Prod 1960; 2: 59-65.

25. Cassady JP, Robison OW, Johnson RK, Mabry JW, Christian LL, Tokach MD, Miller RK, Goodwin RN. National pork producer council material line genetic evaluation: a comparison of growth and carcass traits in terminal progeny. J Anim Sci 2004; 82: 3482-3485.

26. DeVol DL, McKeith FK, Bechtel PJ, Novakofski J, Shanks RD, Carr TR. Variation in composition and palatability trait and relationships between muscle characteristics and palatability in a random sample of pork carcasses. J Anim Sci 1988; 66: 385-395.

27. Irie M. Evaluation methods for pork quality. Jpn J Swine Sci 2002; 39: 221-254 (in Japanese). 